\title{
Impact of Socio-Economic Variables on the Knowledge and Adoption of the Diversified Agriculture Technologies - A Case Study of DASP Adopted Villages of Sasni Block of Hathras District (U.P.), India
}

\author{
Jaspal Singh ${ }^{1}$, Amod Sharma ${ }^{2 *}$ D.B. Tyagi ${ }^{3}$ and S.K. Singh ${ }^{4}$ \\ ${ }^{1}$ CCS, R.B.S. College, Bichpuri, Agra (U.P), India \\ ${ }^{2}$ Department of Agriculture Economics, NU SASRD, Medziphema Campus, District: Dimapur, \\ Nagaland, India \\ ${ }^{3}$ Shri M.S. Degree College, Abidgarh Agra, India \\ ${ }^{4}$ KVK Awagarh, India \\ *Corresponding author
}

\section{A B S T R A C T}

\begin{tabular}{|l|}
\hline Ke y w o r d s \\
$\begin{array}{l}\text { Socio-economic } \\
\text { variables, Knowledge and } \\
\text { adoption, Agriculture } \\
\text { technologies }\end{array}$ \\
\hline Article Info \\
\hline $\begin{array}{l}\text { Accepted: } \\
\text { 22 April } 2018 \\
\text { Available Online: } \\
\text { 10 May } 2018\end{array}$ \\
\hline
\end{tabular}

\section{Introduction}

Diversification is an integral part of the process of structural transformation of an economy. Like other developing economies, Indian economy is gradually diversifying in favour of secondary and tertiary sectors both in terms of their contributions towards National income and employment. However the increase in contributions of secondary and tertiary sectors towards national income is faster as compared to their contribution towards employment. For example, during the past fifty years while the share of agricultural output in the total national output declined from about 50 per cent to about 26 per cent and its share in the employment of workforce has dropped merely from 63 per cent to about 60 per cent (Indian Economic survey, 2004$05)$.

The process of diversification has also set in the agricultural sector, however gradual it may be. For instance the growth of agriculture related enterprises like dairying, fisheries, bee keeping, poultry, horticulture etc. have 
become more prominent as compared to crop production. Even in the crops, superior cereals and other cash crops have replaced the socalled inferior crops like millets, particularly after the advent of new agriculture technology. The pace and pattern of diversification within the agricultural sector, however varies from region to region, as it is contingent on variety of factors such as the prices of different commodities, availability, technology and policy interventions etc.

CAPART (Council for Advancement of Peoples Action and Rural Technology) is playing an important role in improving the rural environment through different time bound projects. Under Rural development activity, the mandate of CAPART is to coordinate all efforts towards advancement of technology relevant to rural areas except for sectors being dealt with by ICAR and its sister organizations. The broad objective of the Council under this is development and dissemination of rural technology. Projects aimed at conducting need-based study, survey and adaptive research and development, administration and dissemination of appropriate technologies amongst the poor are funded under this scheme. A programme of setting up of Technology Resource Centers (TRC, s) was initiated by CAPART under the scheme. These are Voluntary Organizations (VOs) equipped with lab facilities and received annual grants from CAPART for development of appropriate technology and dissemination of the same through network of small VOs within their areas of operation.

CAPART has 19 Technology Resource Centers while several TRC proposals are in the pipeline. In brief, the main goals were to increase the total productivity (decreasing input resources for the same and/ or higher production per unit area by integrating all the village-based activities), initially, UPDASP worked in 75 blocks including Sasni.

\section{Objective}

The present study has been undertaken with the objective, 'To examine socio-economic impact on the knowledge and adoption of technologies for diversified agriculture.'

\section{Hypotheses}

To carry out the study, the hypotheses $\left(\mathrm{H}_{01}\right)$ 'There is no relation between socio-economic variables and knowledge of by the respondents regarding diversified agriculture' and $\left(\mathrm{H}_{02}\right)$ 'There is no influence of socio-economic variables on the adoption of technologies for diversified agriculture' were framed

\section{Materials and Methods}

Commensurate with the objectives of the study, the multi stage stratified random sampling technique was applied. Sasni block in district Hathras of Uttar Pradesh was selected purposely for the study as it provided an excellent back ground for undertaking comprehensive economic analysis of outcome of the two agencies viz. Government department and UPDASP employed over in this block since 1998. This block was also selected by World Bank for the project work as it had scope for complete diversification.

Out of all the villages adopted by UPDASP (Uttar Pradesh Diversified Support Project) in Sasani block, 10 villages were selected randomly and finally 150 cultivators including 75 members and 75 non- members of self-help groups (SHGs) which were randomly selected from all the selected villages and stratified according to farm size groups i.e. small, medium and large farmers. To determine the important independent variables having significant causal relationship with the dependent variables and the predictive abilities of aforesaid selected eight independent variables towards knowledge and 
adoption of diversified agriculture, multiple regression technique was applied. The Herfindahl Index (H.I.) approach was used as a measure of crop diversification,

$$
H . I=\sum_{i 1}^{N} P_{i}^{2}
$$

Where $\mathrm{N}$ is total number of crops and $\mathrm{Pi}$ represent hectarage proportion of the $\mathrm{I}^{\text {th }}$ crop in total cropped area. With the increase in diversification, the Herfinadahl Index would decrease.

Distribution of farmers according to type of diversified agriculture

Two types of diversification were observed in the study area viz. diversification within crops and diversification with milk production enterprises.

Diversification within crops included growing of cash crops (Potato, Sugarcane, oilseeds etc.), vegetable crops, floriculture (rose cultivation) and fruit crops (Mango, Guava etc) in addition to cereals production.

In case of diversification with livestock enterprise mainly Milk production was adopted on a large scale.

Out of the total sample farmers, 44 per cent were adopting diversification within crops while 56 percent with milk production enterprises in addition to cereals production.

As regards different size group, their respective share was about 41 and 59 per cent in small farm size group, 48 and 52 per cent in medium farm size group and 70 and 30 per cent in large farm size group (Table 1). It indicates that the intensity of diversified agriculture with milk production enterprise inversely related with the farm size.
Impact of socio-economic variables on diversified agriculture

The difference of means of the selected socioeconomic variables such as, Age, Caste, occupation and size of land holding were nonsignificant between the SHG member and non-member farmers (Table 2) indicates that both the groups of sample farmers were more or less homogenous in their composition, because of restriction employed in selection of the scale and the sample for getting matching SHG member and non-member groups.

Further, the differences of means between SHG member and non-member in respect to their irrigation facilities, social participation and communication behaviour were positive and highly significant. This is attributed due to the various training exposure, organization of the rural youths under the banner of Self-help Group for group action, exposure to personnel cosmopolites and mass media and such related facilities extended to the SHG member groups by the NGOs and the K.V.K. as a whole.

Nature and Extent of Adoption of Diversified Agriculture Technology

To analyse the impact of diversified agriculture correlation and regression coefficient of selected independent variables were calculated with knowledge about the technologies and adoption of the technology with the total sample.

The independent and the dependent variables were symbolized as under:

\section{Dependent variables}

$Y_{I}=$ Adoption of improved diversified agriculture

$Y_{2}=$ Knowledge of improved diversified agriculture 


\section{Independent variables}

$X_{1}=$ Age

$X_{2}=$ Caste

$X_{3}=$ Education

$X_{4}=$ Occupation

$X_{5}=$ Size of land holding

$X_{6}=$ Irrigation potential

$X_{7}=$ Social participation

$X_{8}=$ Communication Behaviour

\section{Knowledge of improved diversified agriculture technology}

Education, occupation, irrigation facilities, social participation and communication behaviour were found to be significant and positively related to knowledge of diversified agriculture at 1 per cent level of probability (Table 3) indicating that these socio-economic variables have no impact upon the knowledge of diversified agriculture and hence the null hypothesis $\mathrm{H}_{01}$ has been rejected on one hand while on the other age, caste and size of land holding were non-significantly related to knowledge of diversified agriculture technology implies that there is no relation between age, caste size of land holding and knowledge of the respondents for diversified agriculture therefore with respect to these variables the hypothesis $\mathrm{H}_{01}$ has been accepted.

All the eight independent variables together explained 88 per cent of variation in the knowledge of diversified agriculture among the respondents (Table 4). The calculated "F" value of the estimation was 131.44, which was significant at 1 per cent level of probability.

Thus the result implies that all the eight independent variables together accounted for a significant amount of variation for the knowledge of improved diversified agriculture technology $\left(\mathrm{Y}_{2}\right)$. It was also observed that " $\mathrm{t}$ " value was significant for the independent variables viz. age $\left(\mathrm{X}_{1}\right)$, caste $\left(\mathrm{X}_{2}\right)$, irrigation potential $\left(\mathrm{X}_{6}\right)$ and communication behaviour $\left(\mathrm{X}_{8}\right)$ which implies that the multiple interactions of these four variables was more important for predicting knowledge of diversified agriculture technologies.

\section{Adoption of improved diversified agriculture}

Education, irrigation facilities, social participation, communication behaviour and occupation of the respondents were significant and positively related to the extent of adoption of improved diversified agriculture (Table 5) and hence, in relation to these variables the hypothesis $\left(\mathrm{H}_{02}\right)$ has been rejected. While remaining independent variables viz. age, caste and size of land holding which were not significantly related with adoption of improved diversified agriculture technologies by the respondents supported the hypothesis $\left(\mathrm{H}_{02}\right)$.

All the independent variables together explained 85 per cent of variation in the adoption of improved diversified agriculture technologies (Table 6). The calculated "F" value for the estimation was 97.02 and significant at 1 per cent level of probability, which implies that all the independent variables would account for a significant amount of variation in adoption of improved diversified agriculture technologies.

The $b$ values were found significant for age $\left(\mathrm{x}_{1}\right)$ and communication behaviour $\left(\mathrm{x}_{8}\right)$ indicating that these two variables were the most important for predicting adoption of improved diversified agriculture by young participatory farmers.

The regression coefficient were not significant for caste $\left(\mathrm{x}_{2}\right)$, education $\left(\mathrm{x}_{3}\right)$, occupation $\left(\mathrm{x}_{4}\right)$, size of land holding $\left(\mathrm{x}_{5}\right)$, irrigation potential $\left(\mathrm{x}_{6}\right)$ and social participation $\left(\mathrm{x}_{7}\right)$. 
Table.1 Distribution of respondents according to type of diversified agriculture adopted

\begin{tabular}{|l|c|c|c|c|}
\hline Type of Diversification & \multicolumn{4}{|c|}{ Size of land holding } \\
\cline { 2 - 5 } & $\begin{array}{c}\text { Small } \\
\text { (Below 2 ha.) }\end{array}$ & $\begin{array}{c}\text { Medium } \\
(2-4 \text { ha.) }\end{array}$ & $\begin{array}{c}\text { Large } \\
\text { (Above 4 ha.) }\end{array}$ & Total \\
\hline Within crop only & $47(40.87)$ & $12(48.00)$ & $7(70.00)$ & $66(44.00)$ \\
\hline With crops and dairying & $68(59.13)$ & $13(52.00)$ & $3(30.00)$ & $84(56.00)$ \\
\hline Total & $115(100.00)$ & $25(100.00)$ & $10(100.00)$ & $150100.00)$ \\
\hline
\end{tabular}

Table.2 Test of significance for the selected socio-economic variables

\begin{tabular}{|c|c|c|c|c|c|}
\hline \multirow{2}{*}{$\begin{array}{c}\text { S. } \\
\text { No. }\end{array}$} & \multirow[t]{2}{*}{ Variables } & \multirow[t]{2}{*}{ Units } & \multicolumn{2}{|c|}{ Mean Value } & \multirow[t]{2}{*}{ t-Value } \\
\hline & & & SHG members & SHG Non-member & \\
\hline 1. & Age & Years & 23.38 & 23.64 & 0.50 \\
\hline 2. & Caste & Score & 2.08 & 2.03 & 0.63 \\
\hline 3. & Education & Score & 3.49 & 2.95 & $2.91^{*}$ \\
\hline 4. & Occupation & Score & 3.42 & 3.32 & 1.09 \\
\hline 5. & Size of land holding & Hectare & 3.53 & 3.37 & 0.44 \\
\hline 6. & Irrigation facilities & Score & 1.99 & 1.33 & $5.26^{* *}$ \\
\hline 7. & Social participation & Score & 1.94 & 1.06 & $9.75 * *$ \\
\hline 8. & Communication Behaviour & Score & 18.65 & 10.18 & $13.77 * *$ \\
\hline
\end{tabular}

*Significant at 5 per cent, and $* *$ Significant at 1 per cent level of probability.

Table.3 Correlation of selected independent variables with knowledge of improved diversified agriculture technology $\left(\mathrm{Y}_{2}\right)$

\begin{tabular}{|c|l|c|}
\hline S. No. & Independent Variables & Coefficient of correlation ' $r$ ' \\
\hline 1. & $\mathrm{X} 1=$ Age & 0.02 \\
\hline 2. & $\mathrm{X} 2=$ Caste & -0.01 \\
\hline 3. & $\mathrm{X} 3=$ Education & $0.25^{* *}$ \\
\hline 4. & $\mathrm{X} 4=$ Occupation & $0.18^{* *}$ \\
\hline 5. & $\mathrm{X} 5=$ Size of land holding & 0.06 \\
\hline 6. & $\mathrm{X} 6=$ Irrigation potential & $0.59^{* *}$ \\
\hline 7. & $\mathrm{X} 7=$ Social participation & $0.54^{* *}$ \\
\hline 8. & $\mathrm{X} 8$ = Communication Behaviour & $0.78^{* *}$ \\
\hline
\end{tabular}

** Significant at 1 per cent level of probability. 
Table.4 Multiple regression analysis of selected independent variables with knowledge of diversified agriculture $\left(\mathrm{Y}_{2}\right)$

\begin{tabular}{|c|l|c|c|c|}
\hline S. No. & Independent Variables & b value & SE of "b" & t-Value \\
\hline 1. & $\mathrm{X}_{1}=$ Age & 0.598049 & 0.149257 & $4.01^{* *}$ \\
\hline 2. & $\mathrm{X}_{2}=$ Caste & -1.793797 & 0.999458 & $1.79^{* *}$ \\
\hline 3. & $\mathrm{X}_{3}=$ Education & 0.492389 & 0.380708 & 1.29 \\
\hline 4. & $\mathrm{X}_{4}=$ Occupation & 1.028656 & 0.792268 & 1.30 \\
\hline 5. & $\mathrm{X}_{5}=$ Size of land holding & 0.052066 & 0.185944 & 0.28 \\
\hline 6. & $\mathrm{X}_{6}=$ Irrigation potential & 0.147476 & 0.036494 & $4.04 * *$ \\
\hline 7. & $\mathrm{X}_{7}=$ Social participation & -0.575812 & 0.786001 & 0.73 \\
\hline 8. & $\mathrm{X}_{8}=$ Communication Behaviour & 0.789217 & 0.130351 & $6.05^{* *}$ \\
\hline
\end{tabular}

*Significant at 5 per cent, and ** Significant at 1 per cent level of probability

Multiple correlation $\mathrm{R}=0.9398$,

Coefficient of determination $\mathrm{R}^{2}=0.88$,

Calculated $\mathrm{F}=131.44^{*}$,
Std Error est $=7.7845$

Intercept constant $(\mathrm{a})=-34.725$

d.f. $=13.226$

Table.5 Correlation of selected independent variables with nature and extent of adoption of improved diversified agriculture $\left(\mathrm{Y}_{1}\right)$

\begin{tabular}{|c|c|l|c|}
\hline S. No. & \multicolumn{2}{|c|}{ Independent Variables } & Coefficient of correlation "r" \\
\hline 1. & $\mathrm{X}_{1}$ & Age & 0.01 \\
\hline 2. & $\mathrm{X}_{2}$ & Caste & 0.03 \\
\hline 3. & $\mathrm{X}_{3}$ & Education & $0.24^{* *}$ \\
\hline 4. & $\mathrm{X}_{4}$ & Occupation & $0.14^{*}$ \\
\hline 5. & $\mathrm{X}_{5}$ & Size of land holding & 0.08 \\
\hline 6. & $\mathrm{X}_{6}$ & Irrigation potential & $0.35^{* *}$ \\
\hline 7. & $\mathrm{X}_{7}$ & Social participation & $0.56^{* *}$ \\
\hline 8. & $\mathrm{X}_{8}$ & Communication behaviour & $0.76^{* *}$ \\
\hline
\end{tabular}

*Significant at 5 per cent, and** Significant at 1 per cent level of probability

Table.6 Multiple regression analysis of selected independent variables with nature and extent of adoption of improved diversified agriculture $\left(\mathrm{Y}_{1}\right)$

\begin{tabular}{|c|r|r|r|r|r|}
\hline S. No. & & Independent Variables & b-value & SE of “b” & \multicolumn{1}{c|}{ t-Value } \\
\hline 1. & $\mathrm{X}_{1}$ & Age & 0.494658 & 0.174089 & $2.84 * *$ \\
\hline 2. & $\mathrm{X}_{2}$ & Caste & -0.282241 & 1.165741 & 0.24 \\
\hline 3. & $\mathrm{X}_{3}$ & Education & 0.560704 & 0.444047 & 1.26 \\
\hline 4. & $\mathrm{X}_{4}$ & Occupation & -0.100324 & 0.924079 & 0.11 \\
\hline 5. & $\mathrm{X}_{5}$ & Size of land holding & 0.228168 & 0.216880 & 1.05 \\
\hline 6. & $\mathrm{X}_{6}$ & Irrigation potential & 0.069305 & 0.042566 & 1.63 \\
\hline 7. & $\mathrm{X}_{7}$ & Social participation & 0.362526 & 0.916770 & 0.40 \\
\hline 8. & $\mathrm{X}_{8}$ & Communication Behaviour & 0.762844 & 0.152038 & $5.02 * *$ \\
\hline
\end{tabular}

*Significant at 5 per cent, and** Significant at 1 per cent level of probability

Multiple correlation $\mathrm{R}=0.9203$,

Std.error est. $=9.0796$

Coefficient of determination $\mathrm{R}^{2}=0.85$,

Intercept constant $(\mathrm{a})=32.264$

Significance of the Est. F $(\mathrm{Cal})=97.02 * *$,

d.f. $=13.226$ 
Table.7 Crop diversification indices for sample farms (Herfindahl Indices)

\begin{tabular}{|l|c|c|}
\hline Crops & SHG members & Non-SHG members \\
\hline Paddy & 0.0376 & 0.0356 \\
\hline Bajra & 0.1692 & 0.1858 \\
\hline Maize & 0.0451 & 0.0593 \\
\hline Jowar & 0.0150 & 0.0277 \\
\hline Wheat & 0.4060 & 0.4387 \\
\hline Barley & 0.0451 & 0.0316 \\
\hline Total Pulses & 0.0564 & 0.0435 \\
\hline Total oilseeds & 0.0526 & 0.0435 \\
\hline Sugarcane & 0.0376 & 0.0119 \\
\hline Potato & 0.0677 & 0.0553 \\
\hline Tobacco & 0.0150 & 0.0198 \\
\hline Cotton & 0.0226 & 0.0316 \\
\hline Others & 0.0301 & 0.0158 \\
\hline Total & 1.00 & 1.00 \\
\hline EPi & 0.2128 & 0.2422 \\
\hline 1-H.I. & 0.7872 & 0.7578 \\
\hline
\end{tabular}

\section{Crop diversification level}

The Herfindahl Index (H.I.) connotes the extent of dispersion and concentration of activities in a given time and space by a single quantitative indicator. With the increase in diversification, the Herfinadahl Index would decrease. This index takes a value one where there is complete specialization and approaches zero as $\mathrm{N}$ gets large i.e. diversification is "perfect". Since, the Herfindahl index is a measure of concentration; it was transformed by subtracting it from one, to avoid confusion in its comparison with other indices (Table 7).

Herfindahl Index on the farms of SHG members and non-members was 0.2128 and 0.2422 , respectively, indicating increase in diversification in case of SHG members. This was because of comparatively large sized holdings, better financial position and technical assistance under the DASP program which facilitated in growing of variety of cash crops on their farms.

Both the groups of sample farmers were more or less homogenous in their composition with respect to their age, caste, occupation and size of land holding. The positive and highly significant difference of means between SHG member and SHG non-member in respect to their irrigation facilities.

Social participation and communication behaviour was attributed due to various training exposure, organization of the rural youths under the banner of SHG for group action, exposure to personnel cosmopolites and mass media and such related facilities extended to the SHG member groups by the NGOs and the K.V.K. as a whole.

Education, occupation, irrigation potential, social participation communication behaviour have significant and positive impact upon the knowledge of diversified agriculture while there is no relation between age, caste, size of land holding and knowledge of diversified agriculture.

The multiple interactions of age $\left(\mathrm{X}_{1}\right)$, caste $\left(\mathrm{X}_{2}\right)$, irrigation potential $\left(\mathrm{X}_{6}\right)$ and communication behaviour $\left(\mathrm{X}_{8}\right)$ was more important for predicting knowledge of 
diversified agriculture technologies. Education, irrigation potential, social participation, communication behaviour and occupation of the respondents were significant and positively related to the extent of adoption of improved diversified agriculture while age, caste and size of land holding were not significantly related with adoption of improved diversified agriculture technologies.

The significant values of age and communication behaviour were the most important for predicting adoption of improved diversified agriculture by young participatory farmers.

Increase in diversification in case of SHG members was because of comparatively large sized holdings, better financial position and technical assistance under the DASP program which facilitated in growing of variety of cash crops on their farms. The intensity of diversified agriculture with milk production enterprise was inversely related with the farm size.

\section{References}

Economic and Statistical Organization of Punjab, 2000 and various issues. Statistical Abstract of Punjab. Government of Punjab, Chandigarh.

Ghuman, R. S., (2001) "WTO and Punjab Agriculture", paper presented at the Seminar on Globalization and Its Impact on Punjab Economy, Politics, Culture and Language, held at Khalsa College Jalandhar, Punjab, India.

Government of West Bengal, (2000) Economic Review, Calcutta.

Gulati, A., 1999. "From Marrakesh to Seattle: Indian Agriculture in a Globalizing World", Economic and Political Weekly 34(41).
Hireamath, B.N. and Vishwa Ballabh (1996), "Integrating Small Farmers with Market: Problem and Prospects" In Small Farm Diversification: Problems and Prospects (edi) by T. Haque, NSAP, New Delhi, pp. 103-118

Khatkar, R.K., J.P. Singh and B.S. Tomar (1996), "Factors Affecting Diversification of Agriculture in Hisar District of Haryana," Indian Journal of Agricultural Economics, Vol. 51, No. 4, October-December, pp. 703-704.

Kumar, P. (1996), "Structural Change in Consumption and Small Farm Diversification," - Problems and Prospects (edi) by T. Haque, NCAP, New Delhi, pp. 173-180.

Pandey, V.K. and K.C. Sharma, 'Crop Diversification and Self Sufficiency in Foodgrains,' Indian Journal of Agriculture Economics, Vol. 51, No. 4, OctoberDecember 1996, pp. 644-651.

Raman, T. and N.K. Sharda (1996), "Diversification of Agriculture in Himachal Pradesh," Indian Journal of Agricultural Economics, Vol. 51, No. 4, OctoberDecember, pp. 75-706.

Saini, S. (2001) "Economic Analysis of Dairy Enterprise under Mixed Farming System in Baheri Block of Bareilly District (U.P.)". Indian Journal of Animal Science 45(3): 107-110.

Singh, A.K. (1998), "Potential of Diversification Towards High Value Crops in Uttar Pradesh," A Project Report by Giri Institute of Development Studies, Lucknow in collaboration with National Centre for Agriculture Economics and Policy Research, New Delhi.

Vyas, V.S. (1996), "Diversification in Agriculture: Concept, Rationale and Approaches," Indian Journal of Agricultural Economics, Vol. 51, No. 4, OctoberDecember, pp. 636-643.

\section{How to cite this article:}

Jaspal Singh, Amod Sharma, D.B. Tyagi and Singh, S.K. 2018. Impact of Socio-Economic Variables on the Knowledge and Adoption of the Diversified Agriculture Technologies - A Case Study of DASP Adopted Villages of Sasni Block of Hathras District (U.P.), India. Int.J.Curr.Microbiol.App.Sci. 7(05): 3095-3102. doi: https://doi.org/10.20546/ijcmas.2018.705.361 